\title{
Herbal Prevention of Pneumonia Epidemics in Multinational Refugee Camps: Echinacea for Refugees
}

\begin{abstract}
Ali Tafazoli
Keywords

Echinacea $\cdot$ Refugees $\cdot$ Respiratory tract infections
\end{abstract}

Department of Clinical Pharmacy, School of Pharmacy, International Campus, Iran University of Medical Sciences, Tehran, Iran

\section{Summary}

Considering the huge number of war refugees all over the world, taking care of their health-related problems is a critical issue for humanitarian organizations. Respiratory tract infections are one the most life-threatening hazards among these populations. Therefore, any measure to control them with acceptable safety and efficacy will be valuable. According to recent studies, Echinacea supplements are potential candidates for this indication.

(c) 2017 S. Karger GmbH, Freiburg

\section{Schlüsselwörter \\ Echinacea $\cdot$ Flüchtlinge $\cdot$ Atemwegserkrankungen}

\section{Zusammenfassung}

Prävention von Pneumonie-Epidemien in multinationalen Flüchtlingslagern mithilfe von Heilpflanzen: Echinacea für Flüchtlinge

Angesichts der enormen Anzahl von Kriegsflüchtlingen auf der ganzen Welt stellen deren gesundheitsbezogene Probleme ein kritisches Thema für humanitäre Hilfsorganisationen dar. Atemwegsinfektionen sind eine der lebensbedrohlichsten Gefahren für diese Bevölkerungsgruppe, sodass jegliche Massnahme von Wert ist, um diese mit akzeptabler Sicherheit und Wirksamkeit unter Kontrolle zu bringen. Neueren Studien zufolge sind Echinacea-Supplementierungen potenzielle Kandidaten für die Behandlung dieser Indikation.

this setting is exceedingly required. From a historical perspective, nature has frequently helped mankind in such medical crises. Herbal medicine has shown a great capacity for the management of RTIs. As a theoretical candidate, Echinacea supplements would be worthwhile [3].

Echinacea supplements are well-known for immune modulation and anti-RTI effects. This herb does vastly grow in different geographical territories. It is reasonably affordable as well as easily accessible almost all over the world [4]. As a result, this can decrease the cost of transportation of raw materials to the local manufacturing plants. As published previously, there is a huge amount of evidence that shows promising results for the use of Echinacea in both prevention and treatment of RTIs [5]. Also, it would be potentially useful in susceptible travelers such as refugees. It should be noted that despite all documented evidence in the medical literature as well as human experiences, there are some controversial findings in several scientific studies regarding the efficacy of such products. Hence, this approach should be examined further in future clinical trials in order to achieve certainty.

The introduction of an economic, safe, and effective agent with both preventive and therapeutic potential in

\section{KARGER}

Fax +497614520714

\section{(๑) 2017 S. Karger GmbH, Freiburg}

Ali Tafazoli

Department of Clinical Pharmacy, School of Pharmacy

International Campus, Iran University of Medical Sciences

Tehran, Iran

a.tafazzolimoghaddam@sbmu.ac.ir 
In addition, combinations with other immune boosters could help in reaching an assured synergy to fight outbreaks of pneumonia among camp refugees.

\section{Disclosure Statement}

There was no source of funding for the preparation of this study.

\section{References}

1 Chelwa NM, Likwa RN, Banda J: Under-five mortality among displaced populations in Meheba refugee camp, Zambia, 2008-2014 Arch Public Health 2016;74:49.

2 Bellos A, Mulholland K, O’Brien KL, Qazi SA, Gayer M, Checchi F: The burden of acute respiratory infections in crisis-affected populations: a systematic review. Confl Health 2010;4:3.
3 Ross SM: Echinacea purpurea: a proprietary extract of Echinacea purpurea is shown to be safe and effective in the prevention of the common cold. Holist Nurs Pract 2016;30:54-57.

4 Shah SA, Sander S, White CM, Rinaldi M, Coleman CI: Evaluation of Echinacea for the prevention and treatment of the common cold: a meta-analysis. Lancet Infect Dis 2007; 7:473-480.
5 Daneshmehr MA, Tafazoli A: Providing evidence for use of Echinacea supplements in Hajj pilgrims for management of respiratory tract infections. Complement Ther Clin Pract 2016;23:40-45. 